\title{
Vietnam Land Market: Definitions, Characteristics, and Effects
}

\author{
Tran Tuan NGUYEN (Corresponding author) \\ Department of Economic and Social Geography \\ University of Szeged \\ Szeged, Hungary. \\ School of Agriculture and Resources \\ Vinh University \\ Vinh, Nghe An, Vietnam
}

Received: January 15, 2021 Accepted: January 23, $2021 \quad$ Published: January 28, 2021

doi:10.5296/jad.v7i1.18209 URL: https://doi.org/10.5296/jad.v7i1.18209

\begin{abstract}
The land is a vital resource, and the world's powers that want to develop must rely on land as their core. Vietnam is in economic renewal, so whether the country can produce as expected or not depends on how land is used. The land conversion is continuously changing, leading to the constant volatility of the land market. Besides, the land is a unique commodity, and in a socialist country like Vietnam, only land use rights can be bought and sold. The article uses descriptive and explanatory methods to highlight the results that need research. This article also shows Vietnam's land market characteristics through the primary market and the secondary market. This market decentralization creates a two-price mechanism, meaning that a piece of land is priced differently depending on the organization that uses it. This mechanism has created difficulties in producing an available land bank, leading to a reduction in investment attraction in this potential country.
\end{abstract}

Keywords: Land acquisition, compensation, two land price mechanism, Vietnam, land recovery 


\section{Introduction}

It is undeniable the importance of land as a factor of production. It can be considered as the source of all material and wealth. The economic prosperity of a country is associated with an abundance of natural resources. Culturally, the land is the soul of a nation, and its citizens are willing to fight to protect it (Palmer et al., 2009). However, the land is also a commodity, so a land market began to appear. Transactions related to land exist two different types of markets: the service market and the land asset market. A service market is a rental market for use for a specified time. The sale of service land is understood as the land lease or transfer of land exploitation rights at a particular time. Meanwhile, the land asset market occurs when there is a transfer of the land's ownership from the seller to the buyer. Consequently, land markets exist in places where land use rights can be exchanged for the agreed amount or service (Robert et al., 2007).

Unlike other property markets, land markets' development and maintenance involve economic, political, social, and cultural matters (Deininger \& Feder, 1998). Their effects are different for each locality, and it also depends heavily on what is happening in other parts of the national and global economy. In other words, the land market is a complex one. Therefore, from an economic perspective, the land market is described in detail in the form of goods depending on the purpose of land use, such as agricultural land, residential land, or industrial land (Caroline \& Ron, 2002). This view approaches the land market from the commodity's characteristics, from location, information, investment, the inputs, and commodity market outputs. From a regulatory standpoint, the land market is also viewed with connectivity to state-established infrastructure and market-related benefits. The State settings can be referred to as the establishment of land rights, land use planning, land allocation, land lease, and land acquisition.

Along with the renewal and opening up of the economy in 1986, Vietnam has had many industrialization and modernization changes. In particular, Vietnam shows many turning points in attracting foreign investment, which has significantly contributed to developing countries' long-term development. Vietnam has a productive young labor force in parallel with an overall investment attraction, friendly to foreign businesses. Besides, with the attractiveness of stable politics, Vietnam continuously maintains the appeal of foreign direct investment (FDI) after nearly 35 years of renovation. As of August 2020, Vietnam has 32,539 valid projects with a total registered capital of 381.2 billion USD. The accumulated realized wealth of FDI projects is estimated at 223.1 billion USD, accounting for $58.5 \%$ of total valid registered investment capital (Dung, 2020). With a stable annual growth rate of $10.4 \%$ in 2013-2019, South China Morning Post (SCMP) rated Vietnam as one of the critical centers to attract FDI in the world (Bao \& Van, 2020). This predicts a tremendous demand for land use in Vietnam. However, unlike other countries globally, land in Vietnam is owned by the people, so private ownership is not recognized. This issue will result in differences in the purchases and sales in the land market.

This article aims to help readers better overview the land market in a potential economy like Vietnam. Therefore, the next part of this paper is structured as follows. The author will 


\section{MInstitute Macrothink $_{\text {Int }}$}

conduct a documentary review on the importance of land as an economic resource. Then, the research methods are statistically indicated to indicate the characteristics of the land market in Vietnam. The effects of the differences in land price mechanisms on land compensation are also mentioned later. Finally, a conclusion comes with some useful methods for improving land market issues in Vietnam.

\section{Land as the Source of Economy: A Literature Review}

Agriculture and mining industries were the inspiration of many ancient and medieval economists (Robert, 2000; Lowry, 2003). The economic system of that period demonstrated a healthy wealth through feudal domination and the guild system (Brayshay, 2009). In particular, the land as a vital element of the feudal order is the basis of the military, judicial, administrative, and political systems. Mercantilism is economic nationalism that aims to build a rich and powerful state with all its commercialization, with the two primary sources of capital for production, land, and labor (Laura, 2008). This policy aims to achieve a "favorable" trade balance to bring gold and silver into the country and maintain employment. In contrast to the gentile agricultural system of the late 19th and early 20th centuries, the mercantilist system served merchant's and producers' interests, activities that were protected or encouraged by the state. However, when Adam Smith worked on his book "Smith's An Inquiry into the Nature and Causes of the Wealth of Nations" (1776), only a handful of industrial entities existed, and the Industrial Revolution has barely begun. This helps explain his belief that agriculture is a wealth source, not production (Blaug, 1997). For Smith, thanks to two great powers of production, land and labor, agriculture showed higher productivity. Meanwhile, production only witnessed a power of labor.

Karl Marx has also accepted many views of classical economists. For him, the solution to the misery of the masses was a new social structure. Ricardo's theory of worth of labor influenced Marx's theory of values (Lefteris, 1998). He believes that production needs both labor and nature. Marx's labor process is the result of benefiting people through the transformation of natural resources (Perelman, 1979). Marx has also distinguished two ways of viewing goods, including use-value and trade value (Saad-Filho, 2002). The former is the embodiment of useful properties and qualities, while the latter is the embodiment of a certain amount of working time. Marx's often misunderstood the concept of a natural resource is that "nature's free gift" must be understood as "free" in terms of its effect on exchange value (Smith and O'Keefe, 1980). This logic is lumped in the concept of use-value. His concern is to explain the capitalist economy's inner logic. He abstracts from the sphere of utility, concentrating instead on exchange values.

In Neoclassical economics, changing the environment dramatically affects the content of the theory. However, the change in perception leading to the "Neoclassical revolution" is not easily explained (Woodrow et al., 2019). The longevity of the industrial revolution probably shapes the striking characteristics of neoclassical economics. It is also based on the rate of technological development, the shift from a fiber and food-based economy to a fuel-based economy. Economies in the industrialized world appear to be independent of the extractive industries. As a result, the land is subdivided into many different sub-sectors. Many ideas 
developed by classical economists have been incorporated into these fields. The common feature of these domains is that they are land and environmental resources central, and most of their methods are based on the assumptions of neoclassical economics (Van den Bergh, 2007).

Self-interested economic agents are the foundation of Neoclassical economic theory. This theory aims to maximize utility or maximize profit (Mehmet \& Asad, 2012). Therefore, the allocation of land and natural resources is also aimed at maximizing personal production benefits. To achieve this, private manufacturers need to depend on existing technologies, resources, and policies. The indirect market approach is used in resource cases to understand the relationships between marketed goods and environmental quality (Cropper \& Griffiths, 1994). The information found will correct price gaps. From there, market signals related to economic factors will be provided. In a competitive economy, each factor of production is determined by its marginal product value. According to the "accumulation theorem", the total output will be precisely exhausted, leaving no surplus foreclosed. Land and related resources are considered any other factor of production (Fischel, 1985). In the neoclassical model, the same logic applies to all aspects of land or resource use.

In real estate economics, the land is a factor of production and also a product. They both reacted in part to how mainstream economics in the 1950s and 1960s dealt with land and the environment to the environmental and resource economics (De Steiguer, 1995). The land is also a means of producing useful products. As in the agricultural economy, the land is a separate, renewable resource. The land is also an essential factor in the space economy. This includes transport, urban and regional economics, and spatial informatics, mainly geographic information systems (Hubacek \& van den Bergh, 2002).

\section{Methodology}

This paper's primary research method is Desk Research, which deals with secondary data or data collected without field investigation. The data used in the article are through previous reports of the studies. Data was collected from descriptions of the Ministry of Natural Resources and Environment of Vietnam and Vietnam's General Statistics Office. After studying and analyzing documents related to research purposes, the author will synthesize, describe, and analyze Vietnam's land market characteristics. Synthesizing the obtained secondary data and the analysis just mentioned, the author will evaluate the impact of the land market in Vietnam on land conversion, especially in the land acquisition area. Finally, the author will conclude the results that have been studied. 


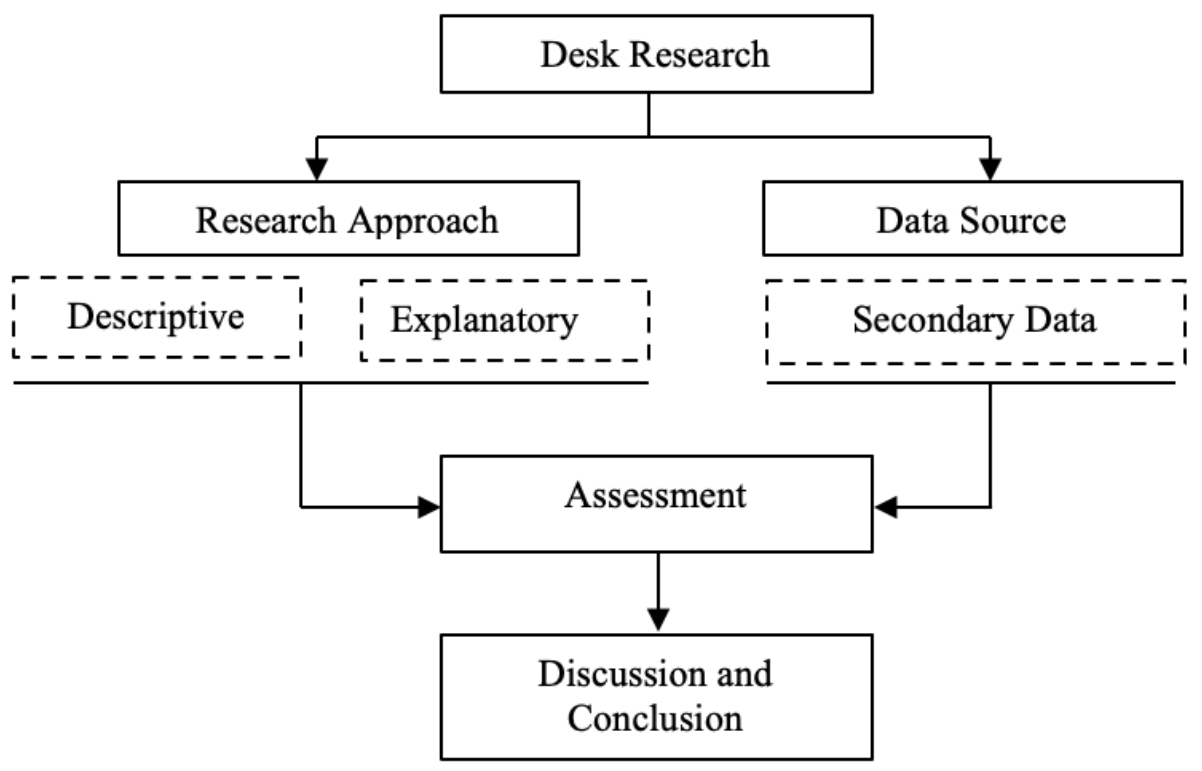

Figure 1. Research Design

\section{Discussion}

\subsection{Land Market in Vietnam}

Before the reforms (1986), the land market did not exist because of the State-owned land. According to Vietnam's law, the State is the only person with one owner's full powers, and land belongs to the people. The State possesses land through cadastral activities: survey, assessment, classification, and cadastral mapping. The State determines land through administrative decisions such as land allocation, land lease, land acquisition, recognition and issuance of land use right certificates, the extension of land use rights, regulation of land use limits, and determining price brackets of land types. The State uses land indirectly through planning, land use plans, or changing the purpose of land use. The State collects land use tax, tax of land use right transfer, fees, and collects land use levy. Therefore, the land market in Vietnam is essentially the market for land use rights.

The land market is an input market and production means, so it can take place in exchange, purchase, sale, transfer, mortgage, and lease. When participating in the land market, land users have been assigned a land-use right by the State. At this point, the primary market is formed. When land is allocated or leased by the State, land users are issued land use right certificates. As a result, they are allowed to participate in civil transactions through the exercise of land use rights. This is called the secondary market. The identification of the primary market and the secondary market for land is only one of the approaches to presenting the initial relations (the State - the user) and subsequent relations (users - users) (Figure 2). 


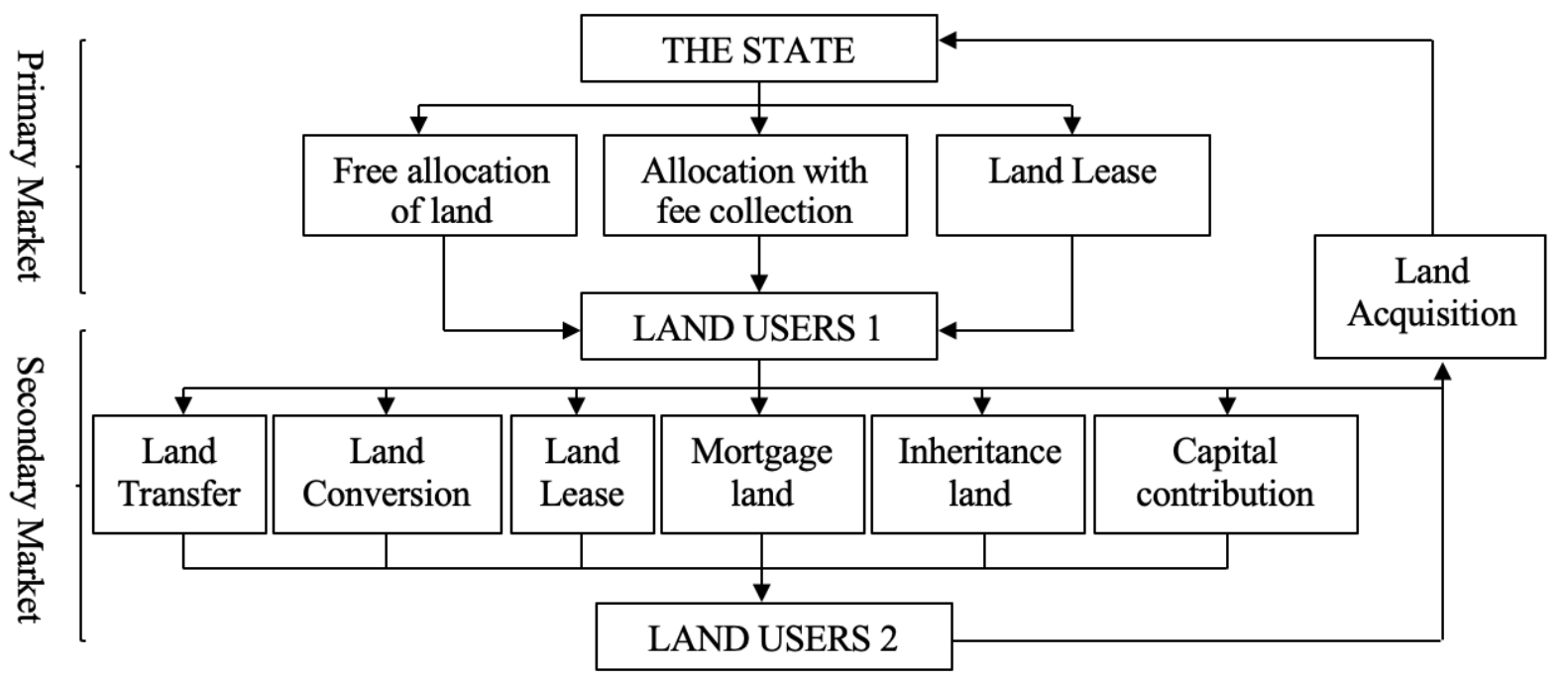

Figure 2. Land market model in Vietnam

The primary market includes transactions between the State as the representative of the entire people owner of the land to allocate or lease land to organizations, households, and individuals in society. These are collectively referred to as land users. Since the 2003 land law, the primary market has operational mechanisms suitable to the market economy, such as the auction of land use rights, bidding for projects with land use, and development of land funds. From there, the recovered land fund is transferred to this market in order to match the market mechanism. When the State acquires land, people have been compensated a price depending on its purpose. (This point of view will be mentioned and discussed in the next section of the article).

Meanwhile, the secondary market is a transaction market between people assigned land use rights by the State and those wishing to use the land again. The forms of transactions are carried out through the six conditions described in Figure 2, such as land transfer, land use purpose conversion, land lease, land mortgage, inheritance, and capital contribution by land. From there, it can be seen that, although the land market in Vietnam was started late, it also fully reflected the nature of a market economy. In the past, the State again intervened to cause market obstacles. For example, investors receive land transfers from current land users. After that, they still have to do procedures to rent land from the State. This issue improved after the 2003 land law came into effect. The State does not interfere in the activities of the market. Instead, the State only manages land use for essential land types such as rice, forest land, and residential land.

The size of the secondary market is entirely dependent on the primary market. In other words, this market is affected by the supply of land allocated by the State to land users. According to statistics from the Ministry of Natural Resources and Environment, the State is increasingly giving more land to land users (Table 1). This figure increases from 25 million hectares in 2011 to nearly 27 million hectares in 2018. In which households are the top priority, accounting for over $50 \%$ of the land used each year. For economic development and 


\section{Macrothink

industrialization, and modernization, land allocated to Domestic Institutions witnessed the most vigorous growth, with nearly 1 million hectares after eight years. However, with strong population growth, Vietnam's housing market has not met the development needs, especially in urban areas. This raises concerns about the disparity between land supply and demand. It will lead to a continuous increase in land prices, putting pressure on the people.

Table 1. Current land use status by users in Vietnam over the years

Unit: thousand ha

\begin{tabular}{llllllll}
\hline & $\mathbf{2 0 1 1}$ & $\mathbf{2 0 1 3}$ & $\mathbf{2 0 1 4}$ & $\mathbf{2 0 1 5}$ & $\mathbf{2 0 1 6}$ & $\mathbf{2 0 1 7}$ & $\mathbf{2 0 1 8}$ \\
\hline $\begin{array}{l}\text { Domestic } \\
\text { Households }\end{array}$ & $15,083.3$ & $14,951.8$ & $15,890.5$ & $15,894.4$ & $15,903.5$ & $15,890.5$ & $15,875.8$ \\
\hline $\begin{array}{l}\text { Domestic } \\
\text { Institutions }\end{array}$ & $9,667.1$ & $10,178.7$ & $10,519.9$ & $10,204.3$ & $9,978.4$ & $10,532.5$ & $10,568.3$ \\
\hline $\begin{array}{l}\text { Foreign } \\
\text { Organizations }\end{array}$ & 56.9 & 54.9 & 45.2 & 45.7 & 46.1 & 46.7 & 46.5 \\
\hline $\begin{array}{l}\text { Communities } \\
\text { and religious }\end{array}$ & 339.7 & 317.3 & 401.1 & 343.3 & 346.5 & 348.9 & 352.3 \\
\hline \begin{tabular}{l} 
Total \\
\hline
\end{tabular} & $\mathbf{2 5 , 1 4 7 . 0}$ & $\mathbf{2 5 , 5 0 2 . 7}$ & $\mathbf{2 6 , 8 5 6 . 7}$ & $\mathbf{2 6 , 4 8 7 . 7}$ & $\mathbf{2 6 , 2 7 4 . 5}$ & $\mathbf{2 6 , 8 1 8 . 6}$ & $\mathbf{2 6 , 8 4 2 . 9}$ \\
\hline
\end{tabular}

Source: MoNRE.

\subsection{Two Land Price Mechanism and the Effect of the Land Market on Land Acquisition}

In the State's land management, the Government has to ensure social, political, and economic stability in theory. At the macroeconomic level, the Government aims to achieve economic stability by determining interest rates. The Government also considers the factors influencing the financial availability that both households and individual developers seek as a goal that needs stabilization. The Government is also responsible for tax collection and national budget development, including infrastructure and development. Consequently, the Government plays a vital role in the land market as policy-makers and law-makers. This role also gives the State the power to price land. In terms of administration, land prices are determined by the State (state price) through different levels. First, it depends on the land price bracket issued by the Government every five years. Second, land prices should be based on land price lists published by the People's Committees of 63 provinces and centrally-run cities based on the Government's price bracket and market land price information. Finally, the specific land price 


\section{Mll Macrothink}

is decided on a case-by-case basis. Meanwhile, the market land price is the transfer price at the time of purchase and sale between one user and another. This means that, in Vietnam, there is a two-price mechanism for land with different price determination, depending on the market demand and the purpose of land use.

There are two forms of land acquisition for project implementation in Vietnam that are the State's compulsory land acquisition and land use right transactions conducted by the investors (voluntary land acquisition) (Figure 3). For land recovered by the State, compensation is determined according to the State's land price bracket. In contrast, market land prices are used in transactions between investors and landholders. This situation leads to conflicts between the types of projects in compensation and negatively affects many different aspects. The reality of implementing legal provisions on land price determination shows that the resolution of land prices to calculate the payment for land acquisition by state agencies tends to be the popular compensation price lower than the market price. Compensation land prices are still imposed and decentralized to Provincial People's Committees for unclear qualitative criteria. This problem leads to the fact that the compensation price does not ensure the right requirement of market price, legal rights, and land users' interests.

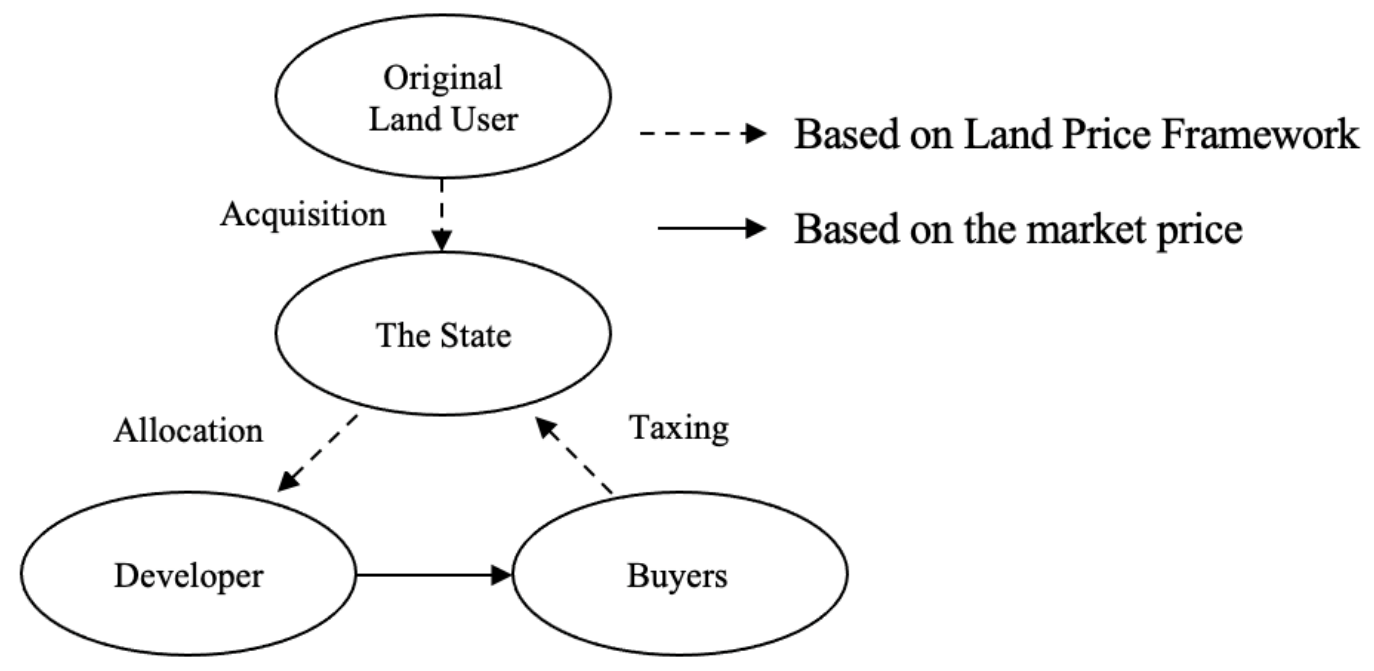

Figure 3. Two land price mechanism

Source: Thu and Perera, 2011.

Provincial People's Committees can be seen as the most responsible agency in assessing land value in land acquisition and compensation. This agency shall base itself on the land price bracket of the State to organize the implementation and issue of the land price list or the adjusted land price list in the locality. Moreover, the land valuation method is also decided by the Provincial People's Committee (There are five land valuation methods approved by the Vietnamese government: a direct comparison, deduction, income, surplus, and coefficients land price adjustment). The compensation cost depends mainly on the determination of the 
compensation price. Therefore, it is difficult for land price determination to comply with the "independent and objective" principle under the 2013 land law. This leads to a large difference between the land price bracket and the market land price.

According to the Ho Chi Minh City Real Estate Association, the highest price of these three local luxury streets is about 210 million $\mathrm{VND} / \mathrm{m}^{2}\left(9,150 \mathrm{USD} / \mathrm{m}^{2}\right)$, according to the State's valuation. This figure is far less than the actual price of this area, about 1.2 billion $\mathrm{VND} / \mathrm{m}^{2}$ $\left(52,300 \mathrm{USD} / \mathrm{m}^{2}\right)$. It is also a misery with agricultural land when the land's compensation level is about $200,000 \mathrm{VND} / \mathrm{m}^{2}\left(9 \mathrm{USD} / \mathrm{m}^{2}\right)$. Still, after a few days of acquisition and project planning, the investor's price will be offered from 30 to 40 million $\mathrm{VND} / \mathrm{m}^{2}$ (1,300 to 1,750 $\mathrm{USD} / \mathrm{m}^{2}$ ). Compared to it, according to Decision No. 96 on regulating land prices of various types in the area of Hanoi city (from January 1, 2014, to December 31, 2019) of the People's Committee of Hanoi, the price of residential land in Hanoi in the central districts of the city, the price is over 100 million $\mathrm{VND} / \mathrm{m}^{2}\left(4,400 \mathrm{USD} / \mathrm{m}^{2}\right)$. The busy old streets were listed with the highest cost of 162 million VND $/ \mathrm{m}^{2}\left(7,000 \mathrm{USD} / \mathrm{m}^{2}\right)$. However, the actual land prices traded on these streets in the market are always much higher, popular from 500 to 800 million $\mathrm{VND} / \mathrm{m}^{2}\left(21,800\right.$ to $\left.34,800 \mathrm{USD} / \mathrm{m}^{2}\right)$. In particular, there are places where the land price on the market is up to 1.3 billion $\mathrm{VND} / \mathrm{m}^{2}$ (56,500 $\mathrm{USD} / \mathrm{m}^{2}$ ) (Long, 2019).

The above shortcomings show the double land price mechanism's impacts on Vietnam's land market and land acquisition. In which, people are considered to be the most damaged when the State recovers land. Ceding land for economic development has accepted immediate risks such as changing livelihoods and changing living environments (Tuan et al., 2019). Therefore, reasonable compensation for the value of the land is something they wish to receive in return. However, the local government also has many difficulties in solving these problems because it has been determined in the local land price list. As a result, land-related claims are showing a sign of increase. According to the General Department of Land Administration (2017) report, land acquisition, compensation, support, and resettlement still have some problems, accounting for $70 \%$ of the land lawsuits.

Land acquisition for economic development is one of the major solutions, creating a driving force for socio-economic development through construction projects such as industrial parks, hi-tech parks, and economic zones. If a country wants to attract more foreign investment projects, an available land supply is essential because it is a crucial manufacturing industry input. However, the analysis above demonstrates that the two-price land system has resulted in a protracted opposition to land acquisition across the country. With difficulties in land acquisition, land supply will be challenging to meet a country's needs in a developing stage like Vietnam. Therefore, site clearance is one of the "bottlenecks" that needs to be removed in the process of attracting investment. In order to solve this problem well, households' rights in the affected area need to be guaranteed through the cost of compensation and support, especially the determination of compensation land prices.

\section{Conclusion}

Vietnam is one of the countries with the fastest economic growth in the world. Political and economic reforms since 1986 have promoted economic development and turned Vietnam 
from one of the poorest countries into a low-middle-income country. GDP per capita increased by 2.7 times, reaching over \$ 2,700 in 2019 from 2002 to 2018 (World Bank, 2020). During the ongoing Covid-19 pandemic, Vietnam also showed considerable resilience. GDP growth estimated at $1.8 \%$ in the first half of 2020 and projected at $2.8 \%$ for the whole year shows a strong potential for Vietnam in the face of shocks. This country is also one of the few countries that do not forecast an economic recession (World Bank, 2020). To achieve this development, attracting investment is the direction that Vietnam is pursuing. The land policy has been gradually perfected in the market mechanism's movement to create greater peace of mind for domestic and foreign investors. However, there are still some obstacles to making land a source of development capital.

The land belongs to the entire people, so Vietnam's land market is the land use right market. Like other commodities, the land market exists in two forms, the secondary land market, and the primary land market. This creates a two-price mechanism for land in Vietnam. The same piece of land, but with different land acquisition methods, will be determined at an additional price. These two prices are determined by the State (land price bracket) and by the market. This difference creates inadequacies in creating land funds for investment attraction because it faces many land users' objections. These questions are among the many reasons that reduce many investors' interest to a potential market like Vietnam. Therefore, to solve these problems, the author would like to give some useful recommendations. First, land prices fluctuate continuously, so the land price bracket needs to be updated regularly to keep up with the changes in land prices in the market. Second, the State must strictly implement the compensation price, close to the market land price. This helps people who have land acquired to benefit a lot. On the State side, once the people's acquired land area is auctioned, a significant amount of money will be collected to compensate for the additional amount of land compensation for people at market prices. Finally, in the long run, the State must build a data information system on land prices, regularly update the changes in land prices across the country, regions, and localities on a practical basis. In addition, transparency of land market information will improve the efficiency of land pricing. The requirement is that the State must make the approved land use plan public, and the land allocation expansion must go through auctions of land use rights.

\section{Acknowledgements}

To make this article more complete, the author would like to thank the followers' comments and editing of this work.

\section{References}

Bao, C. and Van, N. (2020). Việt Nam và những cuộc đua vào tốp đầu thế giới: Kỳ tích FDI và vị thế trong 12 quốc gia thành công nhất thế giới [Vietnam and the world's top races: FDI miracles and position in the 12 most successful countries in the world]. Retrieved December 17, 2020, from https://laodong.vn/thoi-su/viet-nam-va-nhung-cuoc-dua-vao-top-dau-thegioi-ky-tich-fdi-va-vi-the-trong-12-quoc-gia-thanh-cong-nhat-the-gioi-862964.ldo

Blaug, M. (1997). Economic Theory in Retrospect (5th ed.). Cambridge University Press, 
Cambridge. https://doi.org/10.1017/CBO9780511805639

Brayshay, M. (2009). Capitalism and Division of Labor. International Encyclopedia of Human Geography, 390-401. https://doi.org/10.1016/B978-008044910-4.00355-2

Caroline, \& Ron. (2002). The land market with multifunctional land use: how to deal with infrastructure?. European Regional Science Association (ERSA), Dortmund, Germany.

Cropper, M., \& Griffiths, C. (1994). The Interaction of Population Growth and Environmental Quality. American Economic Review, 84(2), 250-254.

De Steiguer, J. E. (1995). Three Theories from Economics about the Environment. Thinking of Biology, 45(8), 552-557. https://doi.org/10.2307/1312701

Deininger \& Feder, (1998). Land Institutions and Land Markets. Development Research Group. The World Bank.

Dung, T. V. (2020). Thu hút nguồn vốn FDI vào Việt Nam và những vấn đề đặt ra hiện nay [Attracting FDI into Vietnam and the current problems]. Retrieved December 14, 2020, from http://tapchitaichinh.vn/su-kien-noi-bat/thu-hut-nguon-von-fdi-vao-viet-nam-va-nhung-van-d e-dat-ra-hien-nay-330589.html

Fischel, W. A. (1985). The economics of Zoning Laws: A Property Rights Approach to American Land Use Controls. The Johns Hopkins Univeristy Press.

Hubacek, K., \& van den Bergh, J. C. J. M. (2002). The role of land in economic theory. IIASA Interim Report. IIASA, Laxenburg, Austria: IR-02-037.

Laura, L. (2008). Mercantilism. In book: The New Palgrave Disctionary of Economics (2nd ed.). https://doi.org/10.1057/978-1-349-95121-5_838-2

Long, X. (2019). Khung giá đất tăng gần hơn giá thị trường [The land price bracket increased closer to the market price]. Retrieved November 22, 2019, from https:/thuvienphapluat.vn/tintuc/vn/thoi-su-phap-luat/nha-dat/26189/khung-gia-dat-tang-ganhon-gia-thi-truong

Lowry, T. (2003). Ancient and Medieval Economics. In book: A Companion to the History of Economic Thought, Edited by Warren, J.S., Jeff, E.B., \& John, B.D., Blackwell Publishing. https://doi.org/10.1002/9780470999059.ch2

Lefteris, T. (1998). Ricardo's Theory of Value and Marx's Critique. History of Economic Ideas.

Mehmet, K., \& Asad, Z. (2012). The empirical evidence against neoclassical utility theory: a review of the literature. International Journal of Pluralism and Economics Education, 3(4): 366-414. https://doi.org/10.1504/IJPEE.2012.052695

National Assembly of the Socialist Republic of Vietnam. (2003). Land law of 2003. Hanoi: National Political Publishing House of Vietnam.

National Assembly of the Socialist Republic of Vietnam. (2013). Land law of 2013. Hanoi: 
National Political Publishing House of Vietnam.

Palmer, D., Fricska, S., and Wehrmann, B. (2009). Toward Improved Land Governance. Land Tenure Working Paper 11. FAO.

Perelman, C. (1979). The Rational and the Reasonable. Philisophic Exchange, 10(1), 5. https://doi.org/10.1007/978-94-009-9482-9_11

Real Estate Association of Ho Chi Minh City (HoREA), (2016). Report on operation result in 2015 and operation plan for 2016, No. 100/BC-HoREA.

Robert, B. E. (2000). Ancient and Medieval Economic Ideas and Concepts of Social Justice. History of Political Economy, 32(2). https://doi.org/10.1215/00182702-32-2-404

Robert, Peter, \& Robin, (2007). Land Markets - Why are They Required and How Will They Develop?. International Federation of Surveyors. Retrieved from https://www.fig.net/resources/monthly_articles/2007/july_2007/july_2007_mahoney_dale_m claren.pdf

Saad-Filho, A. (2002). The Value of Marx: Political Economy for Contemporary Capitalism. Routledge. https://doi.org/10.4324/9780203468272

Smith, N., \& O'Keefe, P. (1980), Geography, Marx and the Concept of Nature. A Radical Journal of Geography. https://doi.org/10.1111/j.1467-8330.1980.tb00647.x

Thu Tr. T., \& Perara, R. (2011). Consequence of the two-price system for land in the land and housing market in Ho Chi Minh city, Vietnam. Habitat International, 35, 30-39. https://doi.org/10.1016/j.habitatint.2010.03.005

Tuan, N. T., Hegedus, G., \& Long, N. T. (2019). Effect of Land Acquisition and Compensation on the Livelihoods of People in Quang Ninh District, Quang Binh Province: Labor and Income. Land, 8(6), 91. https://doi.org/10.3390/land8060091

Van den Bergh, J. C. J. M. (2007). Evolutionary thinking in environment economics. Journal of Evolutionary Economics, 17, 521-549. https://doi.org/10.1007/s00191-006-0054-0

World Bank, (2020). Vietnam Overview. Retrieved October 8, 2020, from https://www.worldbank.org/vi/country/vietnam/overview

Woodrow, W. C., Danilo, B., \& Andrew, D. (2019). Chapter 3 - Intergrated Cross-Disciplinary Studies: Circular Economics With Cases in Japan. In book: Climate Preservation in Urban Communities Case Studies, Elsevier. https://doi.org/10.1016/B978-0-12-815920-0.00003-4

\section{Copyright Disclaimer}

Copyright for this article is retained by the author(s), with first publication rights granted to the journal.

This is an open-access article distributed under the terms and conditions of the Creative Commons Attribution license (http://creativecommons.org/licenses/by/4.0/). 